\title{
Phenetic analysis of Curcuma spp. in Yogyakarta, Indonesia based on morphological and anatomical characters
}

\author{
MULYA SUNGKAWATI ${ }^{1, ~}$, L. HIDAYATI ${ }^{2}$, B.S. DARYONO ${ }^{3}$, PURNOMO PU, $^{4}$ \\ ${ }^{1}$ Faculty of Biology, Universitas Gadjah Mada. Jl. Teknika Selatan, Sleman 55281, Yogyakarta, Indonesia. Tel.: +62-274-580839, \\ Fax.: +62-274-6492355, `email: sungkawatimulya@ gmail.com \\ ${ }^{2}$ Laboratory of Biochemistry, Faculty of Biology, Universitas Gadjah Mada. Jl. Teknika Selatan, Sleman 55281, Yogyakarta, Indonesia \\ ${ }^{3}$ Laboratory of Genetics and Breeding, Faculty of Biology, Universitas Gadjah Mada. Jl. Teknika Selatan, Sleman 55281, Yogyakarta, Indonesia \\ ${ }^{4}$ Laboratory of Plant Systematics, Faculty of Biology, Universitas Gadjah Mada. Jl. Teknika Selatan, Sleman 55281, Yogyakarta, Indonesia. \\ Tel.: +62-274-580839, Fax.: +62-274-6492355, " ${ }^{\text {v }}$ email: purnomods@ugm.ac.id
}

Manuscript received: 2 April 2019. Revision accepted: 26 July 2019.

\begin{abstract}
Sungkawati M, Hidayati L, Daryono BS, Purnomo. 2019. Phenetic analysis of Curcuma spp. in Yogyakarta, Indonesia based on morphological and anatomical characters. Biodiversitas 20: 2340-2347. Curcuma spp., also known as ginger (Zingiberaceae), has economic value in traditional medicine. However, its many morphological variations cause difficulties in identification and classification. Therefore, observation of its morphological and anatomical characteristics, and of the phenetic relationships between Curcuma species, is important. This research aims to determine the specific characteristics of Curcuma spp. and to examine its phenetic relationships based on morphological and anatomical characteristics. The research was conducted in July 2018-February 2019 in the Bantul, Gunungkidul, Sleman and Karanganyar regions. Observation of the anatomical characteristics was conducted on the leaves and rhizomes and the data analyzed according to descriptive and quantitative/numerical methods. Clustering analysis with the Gower General Similarity Coefficient and Principal Component Analysis (PCA) was performed to determine the role of each character in groupings. The results of the research found seven species from 23 OTUs observed (C. aeruginosa, $C$. domestica, $C$. manga and $C$. xanthorrhiza, each with four OTUs; $C$. soloensis and $C$. zedoaria, with three OTUs each; and $C$. heyneana with one OTU) and showed that specific morphological characteristics were found in the flesh color rhizome, pseudostem color and midrib color. Specific anatomical characteristics were evident in the secretion cell color and the presence of trichomes on the leaves and rhizomes. The dendrogram shows a 0.70 phenon line consisting of two groups, group A $(C$. soloensis and $C$. domestica) fused in a 0.760 similarity index, and group B (C. aeruginosa, C. mangga, C. heyneana, C. soloensis, C. xanthorrhiza and C. zedoaria) fused in a 0.654 similarity index, which means that $C$. soloensis and $C$. domestica have a close phenetic relationship. The 0.80 phenon line consisted of five groups: C. domestica, C. soloensis, C. xanthorrhiza, C. zedoaria-C. mangga-C. heyneana and C. aeruginosa.
\end{abstract}

Keywords: Curcuma spp., morphology, anatomy, phenetic analysis

\section{INTRODUCTION}

Curcuma spp., commonly known as ginger (Zingiberaceae), has high value economic. The genus is distributed in Southeast Asia and China, Australia and the South Pacific. The highest diversity of Curcuma L. is in India and Thailand, each with around 40 species, followed by Bangladesh, Vietnam, and Indonesia (Leong-Skornickova et al. 2008). Rhizomes of some species of the genus are utilized for food and medicinal purposes, and are widely cultivated as trade commodities. In Kerala, Indian dried turmeric powder, rice powder, and several other plantderived powders are used as coloring materials in making and decorating. Curcuma species such as C. longa, $C$. aromatica, C. caesia, C. zedoaria (India, China, Thailand, Vietnam, etc.), C. kwangsiensis, $C$. wenyujin, $C$. phaeocaulis (China) and $C$. comosa (Thailand) have been used in a variety of human and veterinary medicines. For example, turmeric paste is smeared topically on the head for vertigo, body sprains, swellings, cuts, wounds, injuries, skin infections, poisonous insect/snake/scorpion bites, pimples, and foul ulcers, and is also used to treat common colds, bronchitis and internal fevers (oral), flatulence, indigestion and diarrhoea (oral), biliary and hepatic disorders, anorexia and diabetic wounds (external or internal) in the Indian countryside (Sasikumar 2005). However, the correct identity of many species is often ambiguous, as different types are traded with same name (Roemantyo 2000).

Backer and Bakhuizen van den Brink (1968) classified the Curcuma genus into three groups: $C$. aurantiaca van Zijp, C. zedoaria (Berg.) Roscoe and C. viridiflora Roxb. In an earlier period, $C$. zedoaria (Berg.) Roscoe was known to have infraspecific taxa, namely $C$. phaeocaulis Val., $C$. xanthorrhiza Roxb., C. aeruginosa Roxb., C. heyneana Val. and v. Zijp, C. mangga Val. and C. sylvatica Val., while Curcuma viridiflora Roxb. had infraspecific taxa of $C$. domestica Val., C. purpurascens Bl., C. colorata Val. C. euchroma Val., C. brog Val., C. soloensis Val., and C. ochrorhiza Val. Later, on these were declared as separate species.

Curcuma spp. has similarities and differences in its characteristics, which can describe the relationship between each individual or species. Morphological characteristics which can be used for identification are often not fully available, and hence supporting data are required to strengthen the classification. Specific morphological and anatomical characteristics have been considered to be 
important data for ascertaining the phenetic relationships between species in a genus. The many morphological variations of Curcuma spp. pose difficulties in its identification and classification of. This research aims to determine the specific characteristics of Curcuma spp. and to examine the phenetic relationships amongst it based on its morphological and anatomical characteristics.

\section{MATERIALS AND METHODS}

The research was conducted during July 2018-February 2019 in Bantul, Gunungkidul, Sleman regions of Yogyakarta, and Karanganyar region of Central Java, Indonesia. Observation of the anatomical characteristics was conducted at the Laboratory of Plant Structure and Development, Faculty of Biology, Universitas Gadjah Mada, Yogyakarta. The study began by sampling the forms of rhizomes, pseudostems, and leaves in the field, documenting the field data by recording the location, habitat and morphological properties of the plants that could not be taken away or represented by samples, together with photographic documentation of the plants. Samples were collected and all accessions of Curcuma plants found were identified using Backer and Bakhuizen v.d. Brink's (1968) guide Flora of Java. Observation of morphological and scoring characteristics The samples were taken then observed for morphological characteristics, which were then scored following Sasikumar's (2005) descriptors in the modified Plant Genetic Resources. A list of the morphological characteristics observed is shown in Table 1. Anatomical preparations for Curcuma spp. used the rhizomes and leaves, together with the free method hand section. Data analysis was performed using descriptive and quantitative/numerical taxonomy. Clustering analysis with the Gower General Similarity Coefficient and Principal Component Analysis (PCA) was conducted using the Multi-Variate Statistical Package (MVSP), version 3.22.

\section{RESULTS AND DISCUSSION}

\section{Morphological characterization of Curcuma spp.}

Morphological characterization of the seven Curcuma species was conducted based on rhizome and leaf characteristics, the species being Curcuma aeruginosa Roxb., Curcuma domestica Val., Curcuma heyneana Val. \& v. Zijp, Curcuma mangga Val., Curcuma soloensis Val., Curcuma xanthorrhiza Roxb., and Curcuma zedoaria (Berg.) Roscoe, with varying morphological characteristics. The habit of Curcuma spp. is herbaceous, with the formation of rhizomes on the roots. Curcuma consists of a pseudostem derived from the leaf midribs and has wide leaves (Tjirosoepomo 1994). Its underground morphology consists of rhizomes and fibrous roots, with some species having a stipitate tuber. Primary rhizomes are ovoid and round in shape, while generally, the secondary rhizomes are elongated, with multiple branching, as in $C$. mangga, $C$. heyneana and C. domestica (Sukarya and Daniek 2013).
Each species has a different color rhizome flesh, which is one of the characteristics that can distinguish them. Based on Figure 1, C. aeruginosa has two different color patterns in the cortex and stele. In the cortex, the color pattern is light yellowish-green, and light greenish-blue in the stele. In $C$. domestica, the color is almost similar, but the stele is darker. C. heyneana and C. mangga have similar colors, namely a brilliant yellow cortex and vivid yellow stele.

Table 1. Scoring and coding of morphological characteristics based on the descriptors of Curcuma spp. in Sasikumar (2005)

\begin{tabular}{|c|c|}
\hline Characteristic & Scoring and coding \\
\hline Habit & $\begin{array}{l}1=\text { small (height }<0.5 \mathrm{~m}), 2=\text { medium (height } \\
0.5-1 \mathrm{~m}), 3=\text { high }(\text { height }>1 \mathrm{~m})\end{array}$ \\
\hline Leaf shape & $\begin{array}{l}1=\text { eliptical, } 2=\text { lanceolate, } 3=\text { oblong- } \\
\text { lanceolate, } 4=\text { ovate }\end{array}$ \\
\hline Leaf apex & $1=$ acuminate, $2=$ acute \\
\hline Leaf margin & $1=$ low wavy, $2=$ medium wavy \\
\hline Midrib color & $1=$ green, $2=$ brownish red, $3=$ brownish purple \\
\hline Leaf base & $1=$ rounded, $2=$ acute, $3=$ cuneate \\
\hline $\begin{array}{l}\text { Leaf upper } \\
\text { surface }\end{array}$ & $1=$ glabrous, $2=$ hairy \\
\hline $\begin{array}{l}\text { Leaf lower } \\
\text { surface }\end{array}$ & $1=$ glabrous, $2=$ hairy \\
\hline Color of blade & $1=$ green, $2=$ dark green \\
\hline $\begin{array}{l}\text { Number of } \\
\text { leaves }\end{array}$ & $1=2-4,2=5-7,3=8-10$ \\
\hline Leaf vein & $1=$ pinnate, $2=$ arcuate \\
\hline $\begin{array}{l}\text { Color of } \\
\text { rhizome flesh } \\
\text { (outer) }\end{array}$ & $\begin{array}{l}1=\text { brilliant yellow (Rhs20159C) } 2=\text { vivid } \\
\text { yellow A (Rhs201512A), 3= light yellow green } \\
\text { (Rhs } 20155 \mathrm{D}), 4=\text { strong orange B } \\
\text { (Rhs } 2015 \mathrm{~N} 25 \mathrm{~B}), 5=\text { strong orange yellow } \\
\text { (Rhs } 201517 \mathrm{~A}), 6=\text { vivid orange yellow } \\
\text { (Rhs } 201523 \mathrm{~A}), 7=\text { pale greenish yellow }\end{array}$ \\
\hline $\begin{array}{l}\text { Color of } \\
\text { rhizome flesh } \\
\text { (inner) }\end{array}$ & $\begin{array}{l}1=\text { strong orange } A, 2=\text { light greenish blue, } 3= \\
\text { vivid yellow } C, 4=\text { strong orange yellow, } 5= \\
\text { strong orange } C, 6=\text { vivid yellow } A, 7=\text { light } \\
\text { yellow green }\end{array}$ \\
\hline Tuber & $1=$ absent, $2=$ present \\
\hline $\begin{array}{l}\text { Rhizome } \\
\text { flavor }\end{array}$ & $1=$ strong, $2=$ low \\
\hline $\begin{array}{l}\text { Rhizome skin } \\
\text { color }\end{array}$ & $1=$ brown, $2=$ brownish orange \\
\hline Rhizome node & $1=$ clear, $2=$ not clear \\
\hline Petiola texture & $1=$ glabrous, $2=$ hairy \\
\hline $\begin{array}{l}\text { Pseudostem } \\
\text { color }\end{array}$ & $1=$ green, $2=$ brownish red \\
\hline Leaf length & $1=15-40 \mathrm{~cm}, 2=41-66 \mathrm{~cm}, 3=67-92 \mathrm{~cm}$ \\
\hline Leaf width & $1=5-13 \mathrm{~cm}, 2=14-22 \mathrm{~cm}, 3=23-31 \mathrm{~cm}$ \\
\hline
\end{tabular}

Table 2. Scoring and coding of anatomical characteristics

\begin{tabular}{ll}
\multicolumn{1}{c}{ Characteristic } & \multicolumn{1}{c}{ Scoring and coding } \\
\hline Vascular bundle type & $1=$ close collateral, 2 = open collateral \\
Stomata type & $1=$ paracytic, 2 = tetracytic \\
Trichome in leaves & $1=$ absent, $2=$ present \\
Trichome type & $1=$ glandular, 2 = non-glandular \\
Secretion cell shape & $1=$ round, $2=$ Oval, $3=$ Polihedral \\
Cell secretion color & $1=$ brownish yellow, $2=$ yellow, $3=$ \\
& pale yellow \\
Trichome in rhizome & $1=$ absent, $2=$ present \\
Trichome type & $1=$ glandular, $2=$ non-glandular \\
Endodermis & $1=$ visible, $2=$ not visible \\
\hline
\end{tabular}




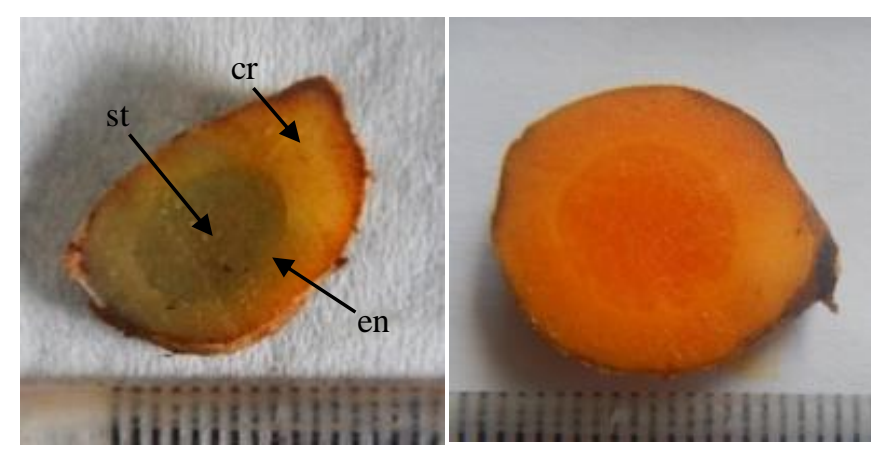

A

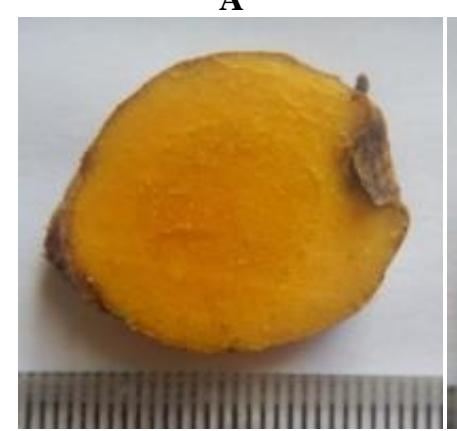

$\mathbf{E}$

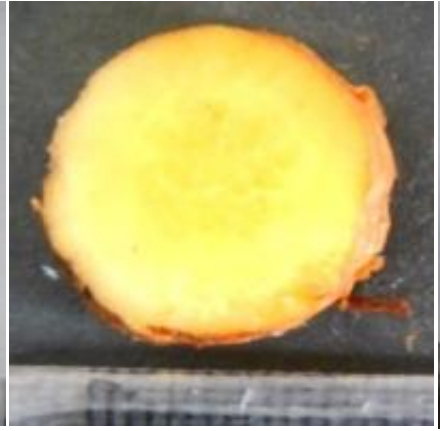

C

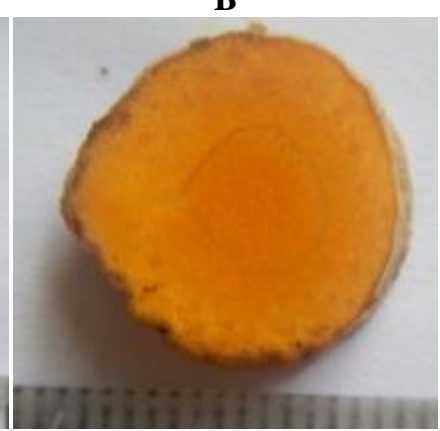

$\mathbf{F}$

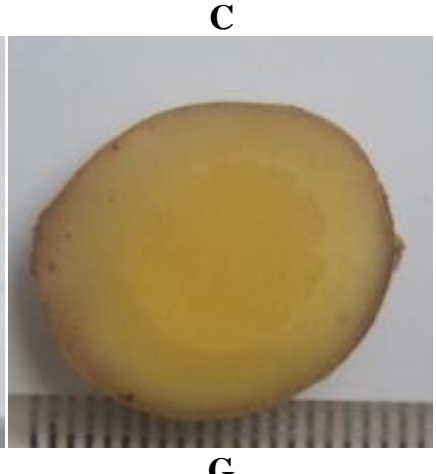

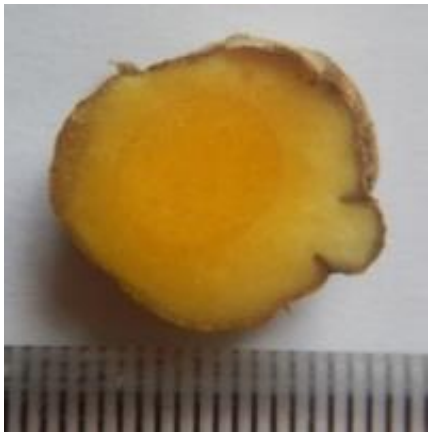

D

Figure 1. Rhizome flesh of Curcuma spp.: A. C. aeruginosa Rhs20155D; B. C. domestica Rhs2015N25B; C. C. heyneana Rhs20159C; D. C. mangga Rhs20159C; E. C. soloensis Rhs201517A; F. C. xanthorrhiza Rhs201523A; G. C. zedoaria. Note: cr (cortex), en (endodermis), st (stele)

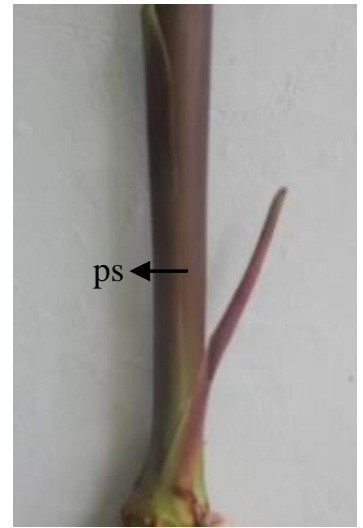

A

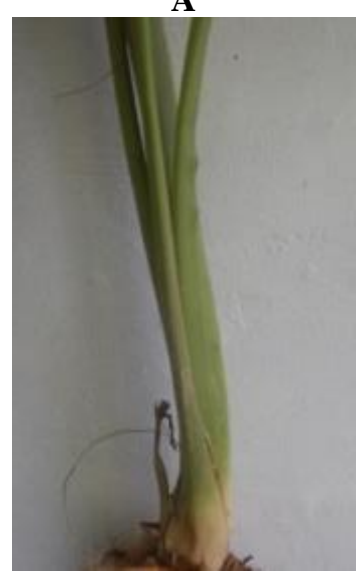

E

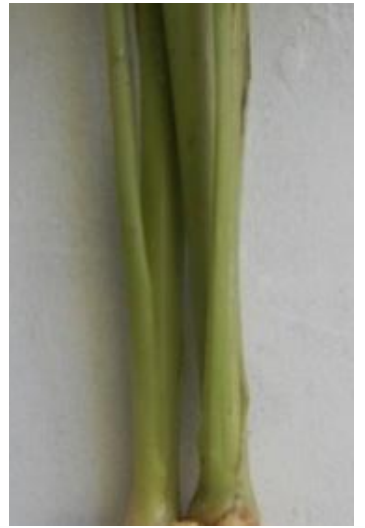

B

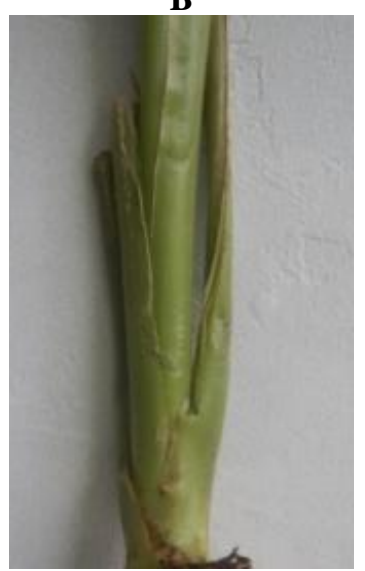

F

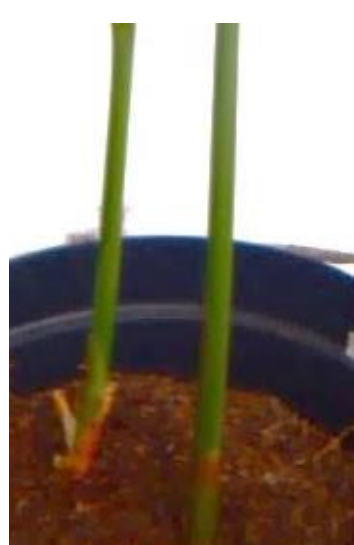

C

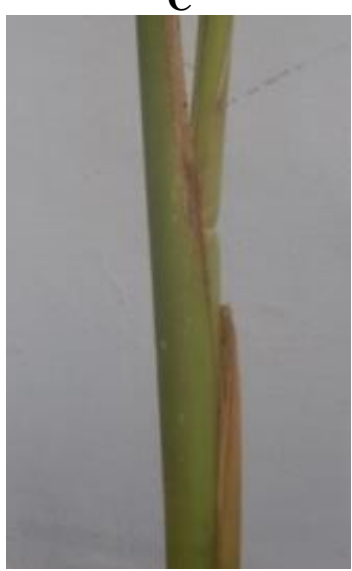

G

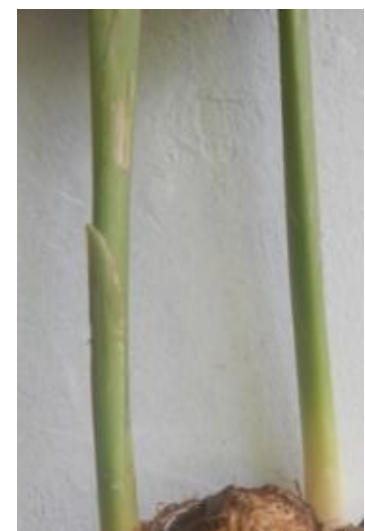

D

Figure 2. Pseudostem color of Curcuma spp.: A. C. aeruginosa, brownish-red; B. C. domestica, green; C. C. heyneana, green; D. C. mangga, green; E. C. soloensis, green; F. C. xanthorrhiza, green; G. C. zedoaria, green. Note: ps (pseudostem) 
The pseudostems of $C$. domestica, $C$. heyneana, $C$. mangga, C. soloensis, C. xanthorrhiza, and C. zedoaria are green, while that of $C$. aeruginosa was brownish-red and green (Figure 2). This color is caused by anthocyanin, which is a natural dye in plants. The presence of anthocyanin is influenced by several factors, especially light intensity, air temperature and soil $\mathrm{pH}$ (Pebrianti et al. 2015).

The leaves of all the studied Curcuma spp. had a glabrous texture on the upper and lower surfaces, pinnate veins, acuminate or acute leaf apex, and elliptic leaf shape, with some species having oblong-lanceolate, ovate and lanceolate leaves. $C$. aeruginosa had a lanceolate and elliptical shape, with a length of $\pm 15-66 \mathrm{~cm}$ and a width of $\pm 5-22 \mathrm{~cm}, 2-7$ leaves, acuminate apex, low wavy margin, cuneate leaf base, the surface color of the upper green and dark green, leaves spreads over the color of the midrib. The color of the midrib is a specific characteristic of $C$. aeruginosa which can distinguish it from other species. According to Singh (2012), C. aeruginosa has a leaf texture on both sides and a dark maroon color on the upper midrib. C. domestica has ovate-and oblong-lanceolateshaped leaves, with a length of $\pm 15-40 \mathrm{~cm}$ and width of \pm 5-13 cm, 2-7 leaves, acute and acuminate leaf apexes, amedium wavy margin, rounded base, and green surface. C. heyneana has an elliptical leaf shape with a length of \pm $15-40 \mathrm{~cm}$ and width $\pm 5-13 \mathrm{~cm}, 2-4$ leaves, an acuminate leaf apex, low wavy margin, and acute leaf base. $C$. mangga has an elliptical leaf shape with a length of \pm 15 $40 \mathrm{~cm}$ and a width of $\pm 5-22 \mathrm{~cm}, 2-10$ leaves, acuminate leaf apex, low wavy leaf margin, and cuneate leaf base. $C$. soloensis has an elliptical leaf shape with a length of \pm 15 $40 \mathrm{~cm}$ and a width of $\pm 5-13 \mathrm{~cm}, 2-10$ leaves, acuminate leaf apex, medium wavy leaf margin, and acute and cuneate leaf base. C. xanthorrhiza has an elliptical leaf shape with a length of $\pm 15-40 \mathrm{~cm}$ and a width of \pm 5-13 $\mathrm{cm}, 2-10$ leaflets, acuminate leaf apex, low wavy leaf margin, acute and cuneate leaf base, green surface color, and green or dark green leaves with a brownish-red color in the midrib. This midrib color is a differentiator from other species. C. zedoaria has an oblong-lanceolate form with a length of $\pm 15-66 \mathrm{~cm}$ and a width of $\pm 5-13 \mathrm{~cm}, 2-4$ leaves, acuminate leaf apex, low wavy leaf margin, and cuneate leaf base. This morphological variation may have occurred due to environmental and genetic factors. The sample obtained from different places with different environmental conditions may also have affected the plants morphological characteristics (Syahid and Heryanto 2017).

\section{Anatomical characteristics of Curcuma spp.}

With regard to the rhizome anatomical characteristics, it had transverse rhizomes consisting of epidermis, cortex, and stele. The endodermis clearly comprised more than one layer. Vascular bundle was spread in the cortex and stele, being a closed collateral type (Trimanto et al. 2018). Each species had secretion cells; $C$. aeruginosa, $C$. heyneana, $C$. mangga, C. soloensis, C. xanthorrhiza and C. zedoaria had round cells, while in $C$. domestica these cells were polyhedral.
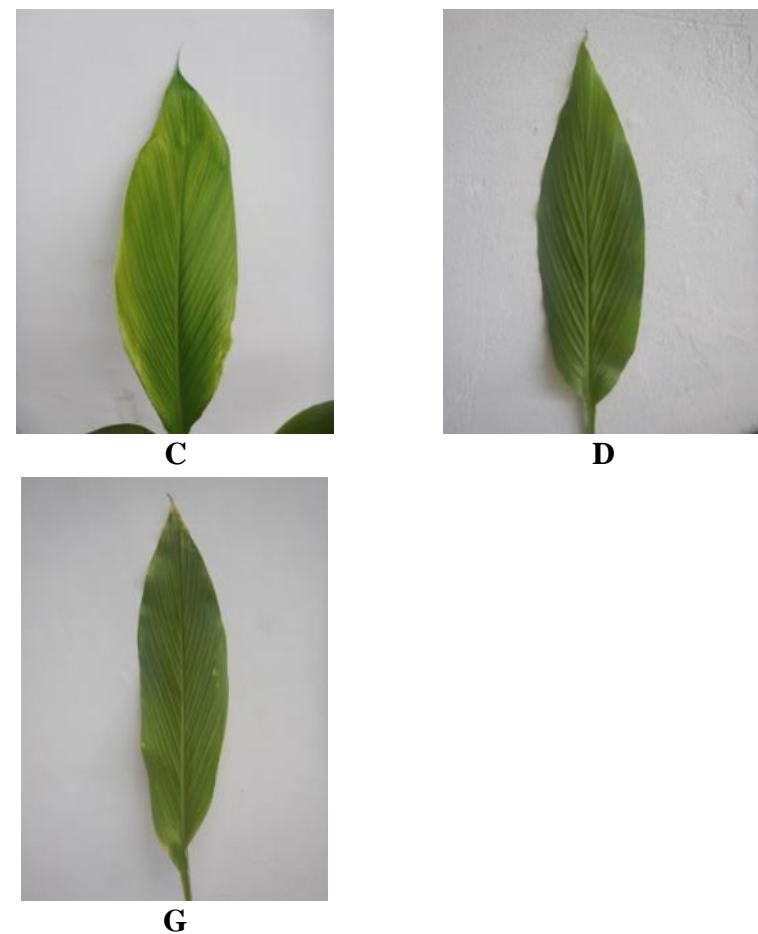

D

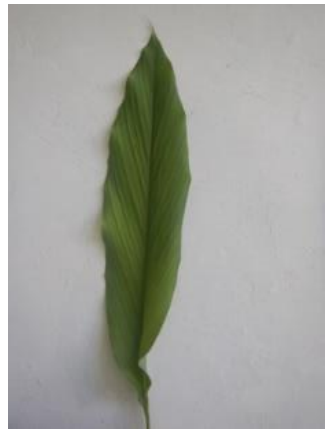

$\mathbf{B}$

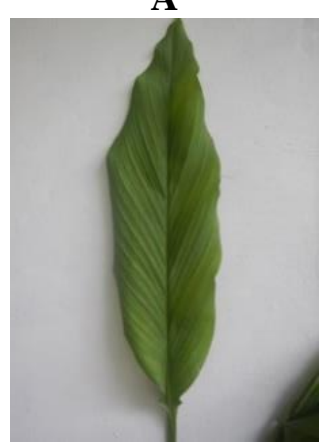

$\mathbf{E}$

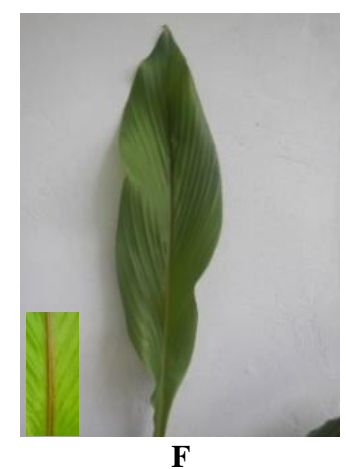

Figure 3. Leaf morphology of Curcuma spp.: A. C. aeruginosa, B. C. domestica, C. C. heyneana, D. C. mangga, E. C. soloensis, F. C. xanthorrhiza, G. C. zedoaria. Note: md (midrib) 
Generally, the color of the secretion cells was yellow, but in some species, it was brownish yellow and pale yellow: pale yellow in $C$. zedoaria and $C$. aeruginosa; brownish-yellow in $C$. aeruginosa and $C$. soloensis; and yellow in the remaining species studied. Trichomes were found in the rhizomes of $C$. heyneana, $C$. domestica, $C$. mangga, C. aeruginosa, C. zedoaria, and C. soloensis, while they were absent in $C$. xanthorrhiza (Figure 4).

The leaf anatomy was composed of three types of tissue: the epidermis, mesophyll and vascular tissue (Soediarto et al. 1991). The Curcuma epidermis consisted of one cell layer; in C. domestica accession Sleman and Gunungkidul, and in C. xanthorrhiza Bantul and Sleman accessions were found to be non-glandular unicellular trichomes in the adaxial epidermis, whereas trichomes were not found in other species. The use of trichomes in taxonomy is well known; some families can be easily identified by the type and shape of these, while in other cases trichomes are important for the classification of genera and species (Soediarto et al. 1991). The mesophyll observed was composed of parenchyma-parenchyma and a transport beam. Undifferentiated mesophyll becomes a palisade and spongy tissue. Bundle vascular is closed collateral, with an air duct between the vascular bundles on the abaxial side. Paradermal incision of the adaxial epidermis showed paracytic stomata in all the species observed. Tetracytic and paracytic stomata are mostly found in Zingiberaceae, Commelinaceae, Cyperaceae, and other families (Scotland and Pennington 2000).

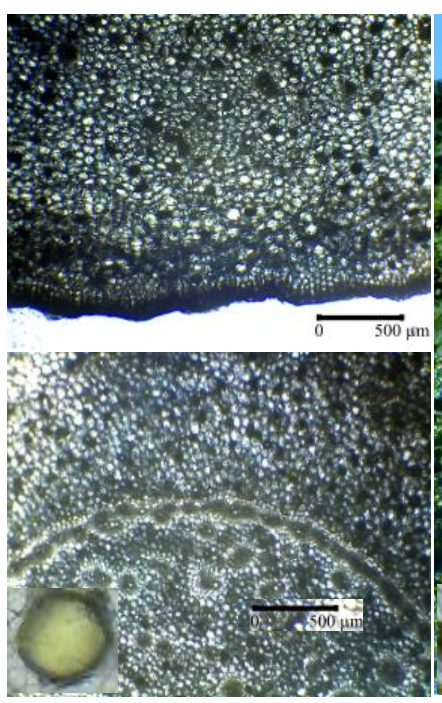

A

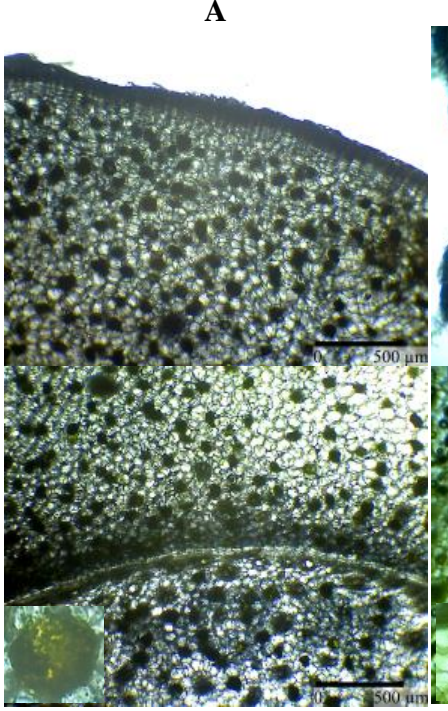

E

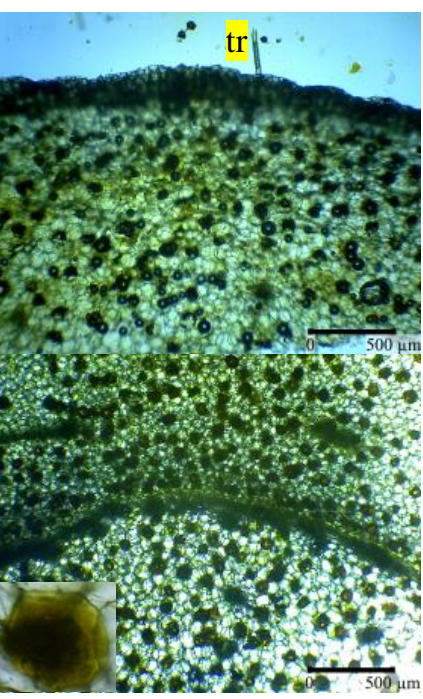

B

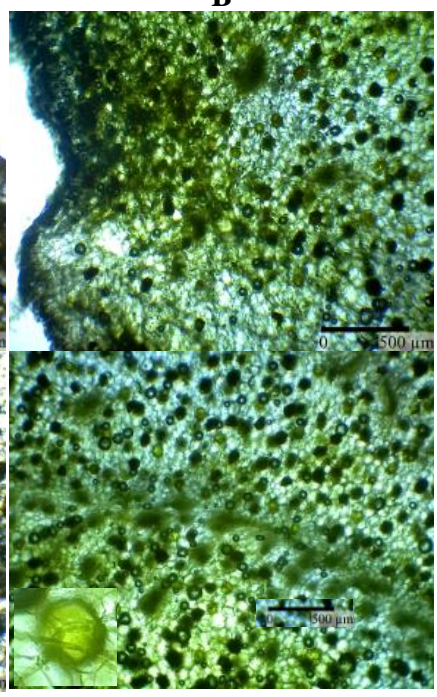

$\mathbf{F}$

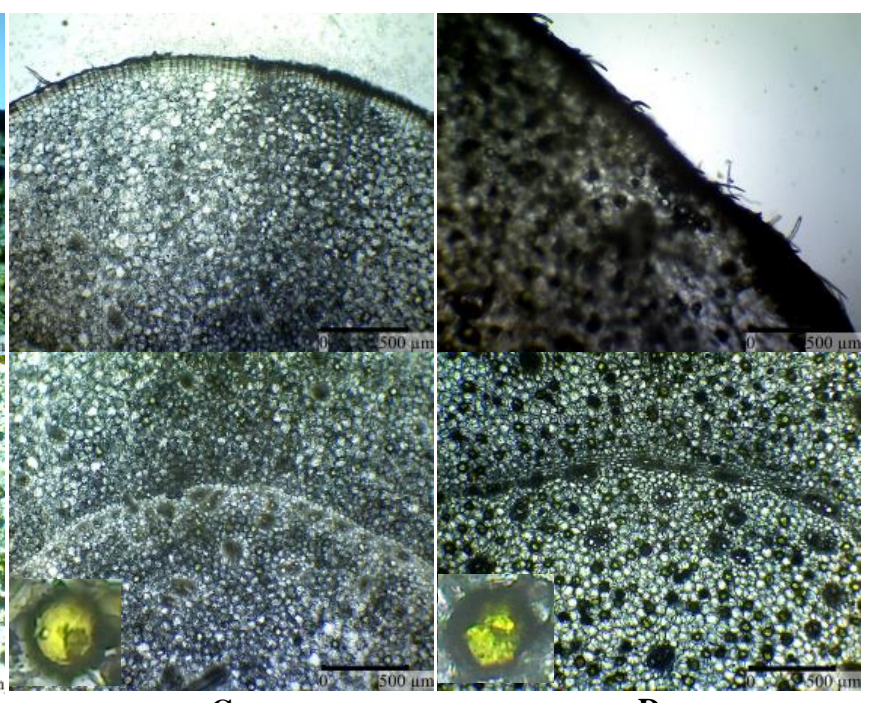

C

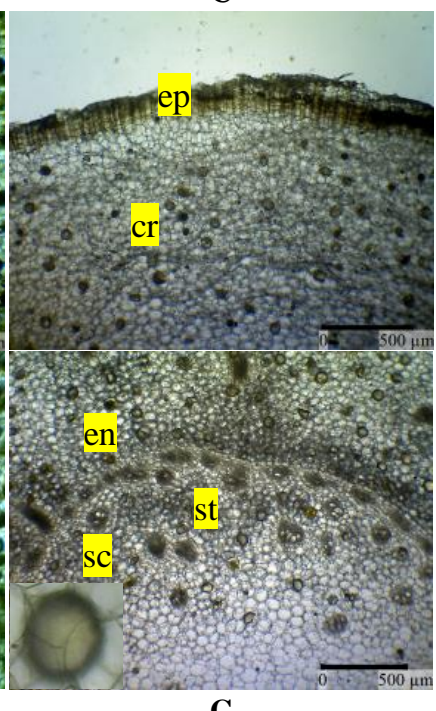

G

Figure 4. Rhizome anatomy of Curcuma spp.: A. C. aeruginosa; B. C. domestica; C. C. heyneana; D. C. mangga; E. C. soloensis; F. C. xanthorrhiza; G. C. zedoaria. Note: ep (epidermis), cr (cortex), en (endodermis), st (stele), sc (secretion cell), tr (trichome) 


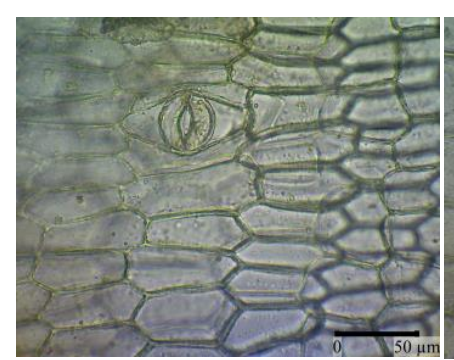

A

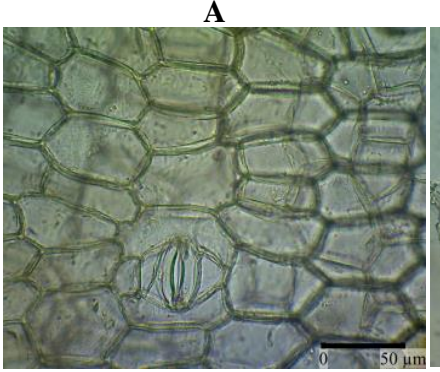

$\mathbf{E}$

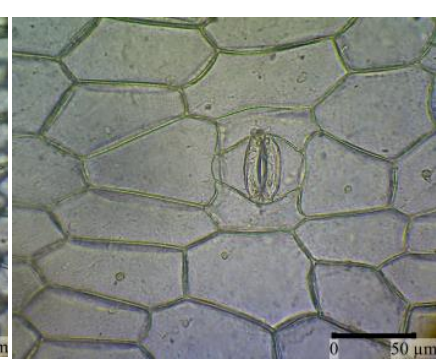

B

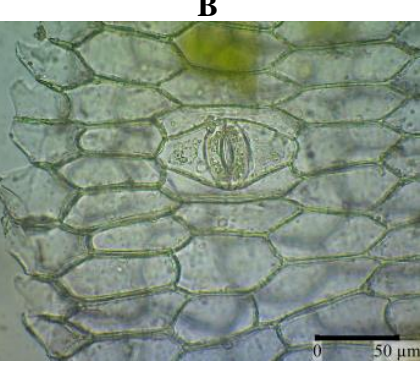

F

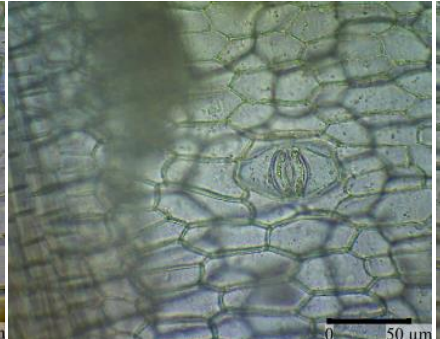

C

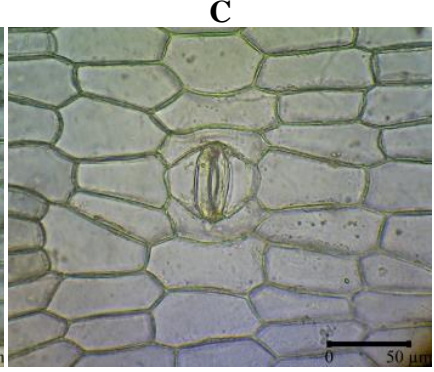

G

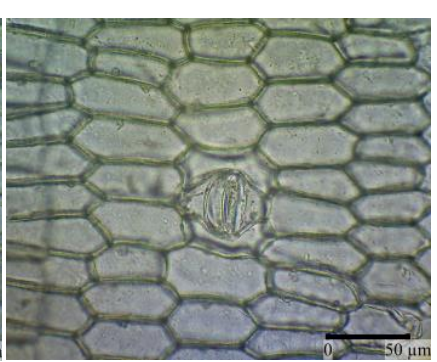

D

Figure 5. Paracytic stomata type of Curcuma spp.: A. C. aeruginosa; B. C. domestica; C. C. heyneana; D. C. mangga; E. C. soloensis; F. C. xanthorrhizha; G. C. zedoaria

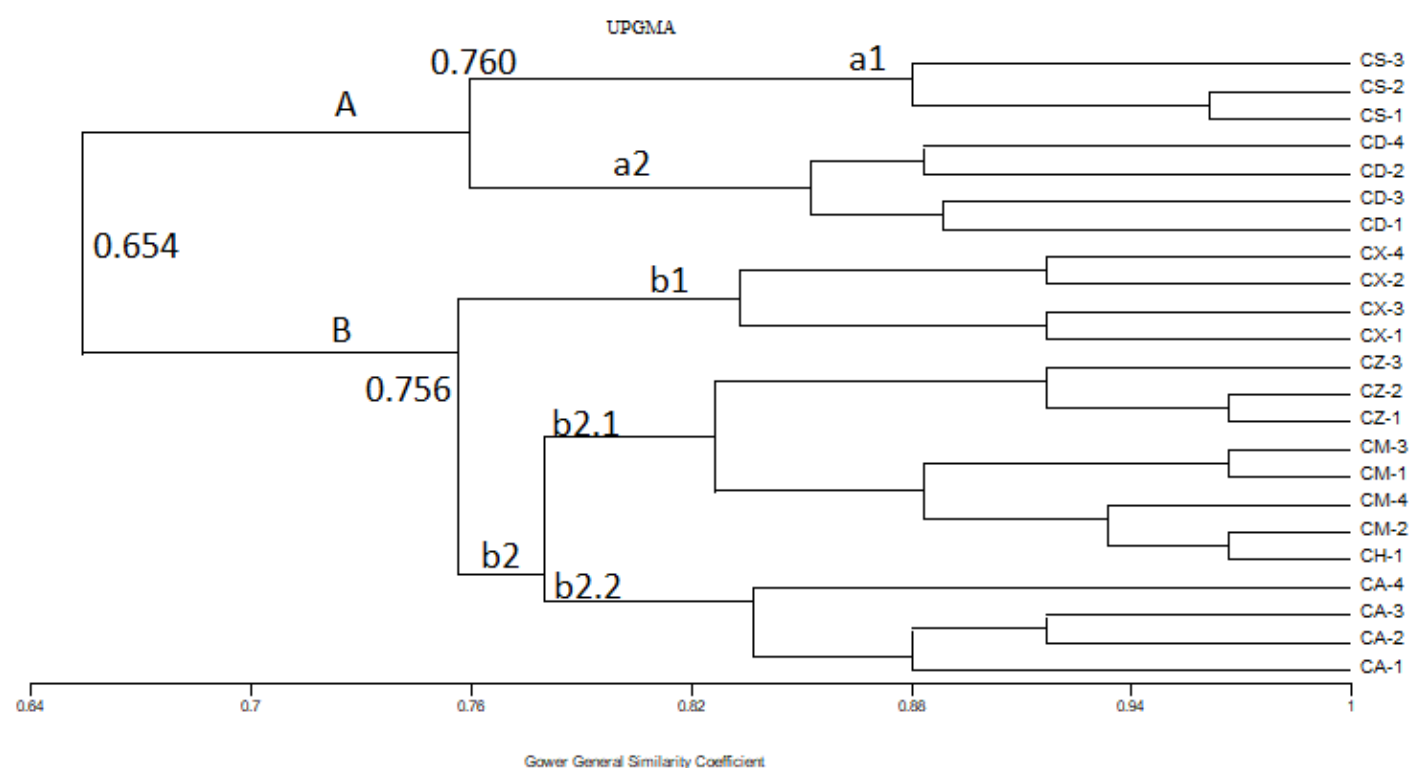

Figure 6. Dendrogram of Curcuma spp. based on morphological and anatomical characteristics, with UPGMA, and the Gower General Similarity Coefficient formula

\section{Phenetic analysis of Curcuma spp. based on morphological and anatomical character}

Based on the dendrogram (Figure 6), it can be seen that the 23 OTUs have several similar morphological and anatomical characteristics, fused in a similarity index value of 0.654. The similarities in anatomical characteristics include the glabrous upper and lower leaf surface texture, the glabrous petiole texture, pinnate veins, visible endodermis, tetracytic stomata type, and close collateral bundle vascular. The dendrogram is divided into two large clusters, A and B. Cluster A consists of seven OTUs and B
16 OTUs. Cluster A comprises C. soloensis and $C$. domestica, while cluster B consists of $C$. xanthorrhiza, $C$. zedoaria, C. mangga, C. heyneana, and C. aeruginosa. Cluster $\mathrm{A}$ is fused in a 0.760 similarity index value, and cluster $B$ in a 0.756 similarity index value. The two clusters are grouped based on leaf margin, rhizome nodes, leaf trichome type, and rhizome trichome type.

Cluster A has two small clusters, a1 and a2. Cluster a1 consists of three OTUs (C. soloensis of Bantul, Gunungkidul and Karanganyar regions) fused in a 0.881 similarity index value. The a 2 cluster consists of four 
OTUs (Curcuma domestica from the Bantul, Gunungkidul, Sleman and Karanganyar regions) fused in a 0.853 similarity index. Cluster B has two small clusters, b1 and b2. Cluster b1 consists of four OTUs, C. xanthorrhiza (from the Bantul, Gunungkidul, Sleman and Karanganyar regions), while the b2 cluster consists of $C$. zedoaria Karanganyar, $C$. mangga and $C$. aeruginosa (from the Bantul, Gunungkidul, Sleman, Karanganyar regions), and C. heyneana from the Bantul region. Purnomo et al. (2012) also classified Dioscorea alata based on morphological characteristics, and its anatomical character in gembili (Purnomo et al. 2013) in infraspecific classification of gembili (Dioscorea esculenta) based on morphology (Purnomo et al. 2017). Purnomo et al. (2018) classified forest potatoes in Yogyakarta based on their morphology and anatomy.

Based on the dendrogram, the 0.70 phenon line consists of two groups: the A group ( $C$. soloensis and $C$. domestica) fused in a 0.760 similarity index, and the B group $(C$. aeruginosa, C. mangga, C. heyneana, C. soloensis, $C$. xanthorrhiza, and $C$. zedoaria) fused in a 0.654 similarity index, which means that $C$. soloensis and $C$. domestica have a close phenetic relationship. Fairuzi (2016) analyzed the phenetic relationships of Curcuma spp. based on morphological and secondary metabolites characteristics; the results of the study showed that $C$. heyneana, $C$. mangga, C. aeruginosa, and $C$. xanthorrhiza were in the same group, and $C$. domestica a different group. The 0.80 phenon line consists of five groups: $C$. domestica, $C$. soloensis, C. xanthorrhiza, C. zedoaria-C. mangga-C. heyneana and $C$. aeruginosa. Generally, the dendrograms show a phenon line that reflects the distance of the phenetic relationship between the study objects. This determines that the threshold value for species is a $85 \%$ phenon line, for genus a $65 \%$ phenon line, and for family a $45 \%$ phenon line (Singh 1999). If some individuals species have a similarity index value of $70 \%$ or more, this shows that they could be considered as a group at the $1 \%$ significance level (Goodall 1966).

The results of the Principle Component Analysis (Figure 7) suggest that characteristics such as the color of the inner and outer rhizomes, leaf shape, rhizome node, presence of trichomes in leaves and rhizomes, and the color and shape of cell secretions greatly influence grouping in each species.

In conclusion, based on the research, it can be concluded that specific morphological characteristics relate to rhizome flesh color, pseudostem color and midrib color, and specific anatomical characteristics to secretion cell color and the presence of trichomes in leaves and rhizomes. The dendrogram shows a 0.70 phenon line consisting of two groups, the A group ( $C$. soloensis and $C$. domestica) fused in a 0.760 similarity index, and B group $(C$. aeruginosa, C. mangga, C. heyneana, C. soloensis, $C$. xanthorrhiza, and $C$. zedoaria) with similarity index of 0.645 , meaning that $\mathrm{C}$. soloensis and $\mathrm{C}$. domestica have a close phenetic relationship. The 0.80 phenon line consists of five groups: C. domestica, C. soloensis, C. xanthorrhiza, C. zedoaria-C. mangga-C. heyneana and C. aeruginosa.

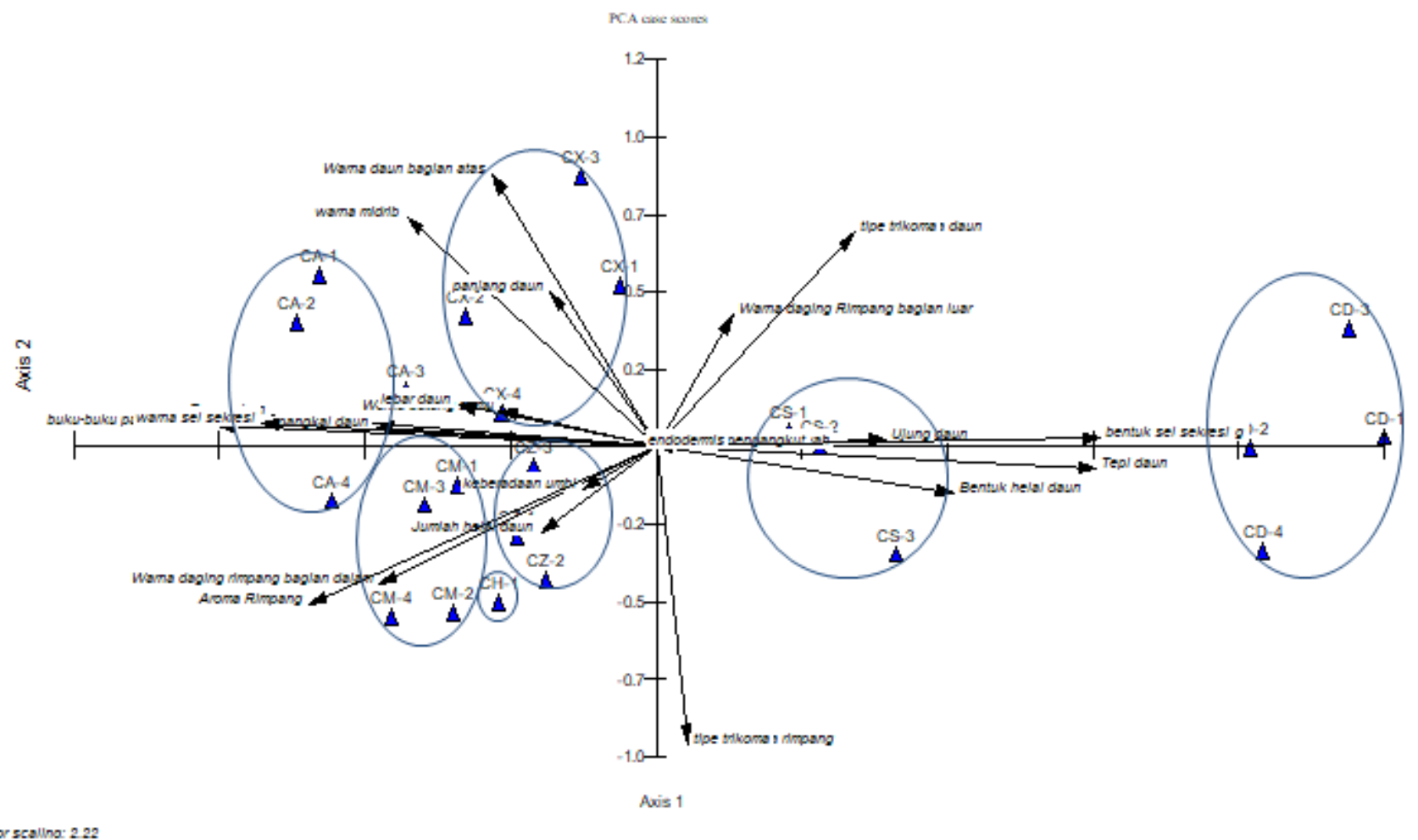

Figure 7. PCA of morphological and anatomical characteristics of Curcuma spp. 


\section{ACKNOWLEDGEMENTS}

This research was supported by the Laboratory of Plant Systematics, and the Laboratory of Plant Structure and Development, Faculty of Biology, Universitas Gadjah Mada (UGM) Yogyakarta, Indonesia. Special thanks to PUPT UGM for funding the research through Hibah Biovir PUPT UGM year 2018, No.: 1984/UNI/DIT-LIT/LT/2018.

\section{REFERENCES}

Backer CA, Bakhuizen van den Brink RC Jr. 1968. Flora of Java Wolters-Noordhof NV. Groningen, The Nederland.

Fairuzi N. 2016. Analisis Hubungan Kekerabatan Curcuma spp. Berdasarkan Krakter Morfologi dan Metabolit Sekunder. [Hon. Thesis]. Universitas Air Langga. Surabaya. [Indonesian]

Goodall DW. 1966. Numerical taxonomy of bacteria-some published data re-examined. J Gen Microbiol 42: 25-87.

Pebrianti, Ainurrasyid C, Purnamaningsih. 2015. Uji kadar antosianin dan hasil enam varietas tanaman bayam merah (Alternanthera amoena Voss) pada musim hujan. Jurnal Produksi Tanaman 3 (1): 27-33. [Indonesian]

Leong-Škorničková J, Sida O, Sabu M, Marhold K. 2008. Taxonomic and nomenclatural puzzles in Indian Curcuma: the identity and nomenclatural history of $C$. zedoaria (Christm.) Roscoe and $C$. zerumbet Roxb. (Zingiberaceae). Taxon 57 (3): 949-962

Purnomo, Daryono BS, Rugayah, Sumardi I, Shiwachi H. 2012. Phenetic analysis and intra-specific classification on Indonesian water yam germplasm (Dioscorea alata L.) based on morphological characters. SABRAO J Breed Genet 44 (2): 277-291.
Purnomo, Faizah LN, Daryono BS. 2017. Variability and intraspesific classification of gembili (Dioscorea esculenta (Lour.) Burk.) based on morphological characters. SABRAO J Breed Genet 49: 1-8.

Roemantyo. 2000. Analisis distribusi spasial marga Curcuma di Jawa. Berita Biologi 5 (2): 203-215. [Indonesian]

Rosmilawati, R. 2016. Studi anatomi daun, analisis struktur sekretori, dan histokimia rimpang temulawak (Curcuma xanthorrhizha Roxb.). [Hon. Thesis]. Departemen Biologi, Fakultas Matematika dan Ilmu Pengetahuan Alam. Institut Pertanian Bogor, Bogor. [Indonesian]

Sasikumar B. 2005. Genetic resources of Curcuma: diversity, characterization and utilization. Plant Genet Resour 3 (2): 230-251.

Scotland R, Pennington T. 2000. Homology and Systematics. CRC Press, Boca Raton, FL.

Singh G. 1999. Plant Systematics an Integrated Approach. Science Publisher. United States America.

Soediarto A, Trenggono RM, Natasaputra M, Akmal H. 1991. Anatomi Tumbuhan. Edisi ketiga. Gadjah Mada University Press, Yogyakarta. [Indonesian]

Sukarya, Daniek. 2013. 3500 Plant Species of the Botanic Gardens of Indonesia. PT Sukarya \& Sukarya Pandetama, Indonesia.

Syahid, Heryanto. 2017. Short Communication: Morpho-agronomic characteristics of twelve accessions of white turmeric (Curcuma zedoaria) germplasm. Biodiversitas 18 (1): 269-274.

Tjitrosoepomo G. 1994. Taksonomi Tumbuhan Obat-obatan. Gadjah Mada University Press, Yogyakarta. [Indonesian]

Tjirosoepomo G. 2013. Taksonomi Umum (dasar-dasar taksonomi tumbuhan) cetakan ke 5. Gadjah Mada University Press, Yogyakarta.. [Indonesian]

Trimanto, Dwiyanti D, Indriyani S. 2018. Morfologi, antomi, dan uji histokimia rimpang Curcuma aeruginosa Roxb, Curcuma longa L, dan Curcuma heyneana Valeton dan Zijp. Jurnal Ilmu-ilmu Hayati. 12 (2): 123-133. [Indonesian] 